\title{
PARTICIPATION OF BRAYUT VILLAGE SOCIETY ON THE DEVELOPMENT OF TOURISM VILLAGE BASED ON ECOTOURISM AS A REPRESENTATION OF HUMAN NATURE PHILOSOPHY
}

\author{
Fadhila Rachmadani \\ Program Pascasarjana Ilmu Filsafat \\ Fakultas Filsafat Universitas Gadjah Mada \\ Email: rachmadanifadhila45@gmail.com
}

\begin{abstract}
ABSTRAK
Krisis lingkungan merupakan persoalan yang berdampak serius bagi kehidupan di bumi. Masalah kekeringan, perubahan iklim, serta penurunan daya tahan lingkungan merupakan bagian dari krisis lingkungan yang disebabkan oleh intervensi manusia terhadap lingkungan di sekitarnya. Tulisan ini membahas satu studi kasus tentang partisipasi masyarakat desa wisata Brayut, Pendowoharjo, Sleman, Daerah Istimewa Yogyakarta dalam pengembangan desa wisata berbasis ecotourisme. Brayut mengembangkan desa wisata berbasis ecotourisme guna mempertahankan kelestarian alam pada lingkup pertanian. Partisipasi masyarakat desa wisata Brayut, Pendowoharjo, Sleman, Daerah Istimewa Yogyakarta dalam mengimplementasikan konsep ekowisata merupakan suatu bentuk sikap kesadaran lingkungan yang ditunjukkan kepada khalayak sebagai suatu respon terhadap tanda-tanda krisis lingkungan di Kawasan Pendowoharjo, Sleman, Daerah Istimewa Yogyakarta sekaligus sebagai cermin filsafat kecenderungan alami manusia yang menunjukkan sikap tanggung jawab manusia terhadap lingkungannya.
\end{abstract}

Kata kunci: Desa wisata; Ekowisata; Human nature philosophy; Partisipasi masyarakat; Sikap kesadaran lingkungan.

\begin{abstract}
The environmental crisis is a problem that has a serious impact for life on the earth. Drought, climate change, and environmental degradation are the part of the environmental crisis which is caused by human intervention to the environment. This paper is discussesed a study case about participation of Brayut Village society, Pendowoharjo, Sleman, Yogyakarta Special Region in developing of tourist village based on ecotourism. Brayut has developed the village based on ecotourism in order to maintain the natural conservation which is concern on agriculture. The participation of Brayut society in the implementation of ecotourism is represents environmental awareness attitude which is deliver a point to the public about a response to the environment crisis in Pendowoharjo, Sleman, Yogyakarta Special Region. Also as a reflection of human nature philosophy that shows a human responsibility to the environment.
\end{abstract}

Keywords: Ecotourism; Environmental awareness attitude; Human nature philosophy; Participation of society, Tourism village. 


\section{INTRODUCTION}

During the 1990s, tourism exploded across the world stage. According to the World Travel and Tourism Council, tourism generates nearly $11 \%$ of global gross domestic product (GDP), employs some 200 million people and transports nearly 700 million international travellers peryear - a figure expected to double by 2020 . The World Tourism Organization reports that tourism is one of the top five exports for $83 \%$ of countries and the main source of foreign currency for at least 38\% of countries. Even if we account for any possible statistical errors, the bottom line fact is indisputable - tourism is growing, and growing fast in many places such as in a west world, east world, including Asia. Ecotourism within its broadly historical context, in order to chart the major of philosophical and social currents that have contributed to its development. We approach this chapter's question by looking closely at the human-nature relationship and the interaction between them.

Laments that although the presence of a conservation ethic is resulting in a move to resource-conserving behavior; there is still a lack of recognition of the intrinsic value of nature. Indeed, many have argued that the remedy for our environmental predicament lies precisely here, in a change of values. However, it is a little real import to identify a certain set of values and to claim that we need simply to change them. Only by understanding the complexity of relations and the historical ideas that have contributed to our current position we can begin to make sense of the 'ethic' or behaviors that these values underpin (Holden, 2005: 339-52).

Sleman Regency is a strategic area for Yogyakarta Special Region because it is an agricultural area and as a source of water conservation in Yogyakarta. Sleman is also a fast growing area because this area is a center of education. The process of urbanization occurs very fast due to the conversion of land from agriculture into settlements triggered by the campuses as a center of growth. The emergence of tourist villages in northern Sleman is expected to limit the conversion of the land considering the rural behavior that is likely to sustain the development of their tourism potential (Hwang, 2012: 21).

Al Sudarmadi, the Head of Brayut Tourism Village Group, supported a rural agricultural activities as evidenced by their efforts to increase the utilization of three dams relic of colonial located in residential areas and paddy in Brayut. The dam, which is located in the north of Brayut Village named Kebo Kuning, then in the east named Sejengkol, and in the south called Slingi. The dam in the village of Brayut in general has never experienced drought, because rivers along the dam are filled with various trees with strong roots. The trees along the river banks of Brayut Village have strong roots that function to absorb the volume of water in large quantities. The variety of trees that grow in green spaces along the banks of the river Brayut Village, namely Klueh, Cangking, Pereh, and Gayam, and Beringin. The various trees are good reservoirs of springs as they have strong roots with wide reaches deep underground (Susilarto, 2016).

Brayut Village, surrounded by the area which is dominated with rice fields. Brayut fields is located in the vicinity of residential neighborhoods that specifically surrounding the village. Rice fields in the village of Brayut planted with rice crops and crops are not entirely planted on the same land. Rice crops are planted to the east of the Brayut residents, while crops of palawija are planted in the west of the Brayut residents. This is determined by the level of fertility as well as the flow of water flowing from the irrigated agricultural dam of Brayut Village. Rice fields to the east of the Brayut settlement relatively close to dams and rivers make the land more suitable for rice cultivation. Rice fields to the west of the Brayut settlement away from rivers and dams cause the land to be more suitable for cultivating crops (Sudarmadi, 2016).

Rice fields in Brayut Village in ancient times had three periods of cultivation within 12 months by planting one type of plant as the main agricultural commodity of Brayut Village that is rice. Distribution of 12-month planted periods in paddy fields in ancient 
Brayut Village in the form of paddy-rice-rice, adjusting to the amount of agricultural irrigation water supply from the Dasa tributaries as well as the capacity of irrigation water in three traditional dams. The amount of agricultural irrigation water supply in Brayut Village originating from the tributary of Dasa River, is still abundant because of several factors such as the area of settlement of Brayut society which has not been too dense and the natural condition that has not been affected by climate change problem (Susilarto, 2016).

Agricultural irrigation water supply in the village of Brayut along with the times, slowly decreased. Agricultural irrigation water supply in present-day Brayut Village is no longer as large as in the past due to the increasingly crowded facto $r$ of settlements in Brayut Village and the negative impacts of global warming affecting climate change or seasonal changes. The agricultural irrigation system of Brayut Village which has Kebo Kuning Dam, Sejengkol and Slingi is still classified as capable of providing irrigation water sources for agricultural activities such as planting of rice crops by applying the time frame pattern of three periods of cultivation during one year of rice-p a ddy-rice. Along with the development of the era, now the pattern of time provision of three periods grown for one year turned into rice-rice-palawija (Susilarto, 2016).

This paper is a part of philosophical research which is used as a final assignment to graduate from study program of Master Philosophy, Faculty of Philosophy, Gadjah Mada University. The method that used in this paper is qualitative with the method of data retrieval in the form of interviews and observation. Writing as a basis on the philosophical research is inseparable from the characteristics of philosophical research which is stick to the primary data source in the form of a study of the original text that obtained from the archives of tourist village in Brayut. Original text data which is belonging to Brayut villagers in the form of Inventory of Agricultural Irrigation System of Brayut Village and supporting data in the form of the interview were obtained through the interview process of two speakers who were directly involved in the activities of Brayut village along with the agricultural activities of Brayut village. Therefore, the data sources obtained from interviews and field observations are secondary data sources that complement or support primary data sources.

The philosophical research that became a basis in the preparation of this paper discusses the village tourism Brayut, Pendowoharjo, Sleman, Yogyakarta Special Region with a focus on the discussion of traditional agricultural irrigation systems belonging to the tourist village of Brayut as a representation of the concept of space and time cosmology. The research then made an inspiration in making this paper is to discuss about the village of Brayut tourism by reviewing some aspects relevant to the theme of environmental crisis. This paper reviews many aspects of Brayut tourism village such as the participation of Brayut villagers in the development of ecotourism-based, ecotourism village, and the environmental impacts of the development activities of the village of nature tourism, especially the agricultural tourism village in Brayut, Pendowoharjo, Sleman, Yogyakarta Special Region.

The discussion in this paper also more specifically adds the point of view of human nature philosophy as a perspective to explore more deeply about the environmental impacts by the people of Brayut tourism village that develop ecotourism. The point of view of human nature philosophy in this paper is certainly oriented to an abstract value as directed to the harmony of reality between man and nature or man with his environment. Thus, the results of research showing that the harmonious relation between man and nature-which in this case is the people of the village of Brayut with nature and the surrounding environment-represents a human nature philosophy that redirects humans to nature that is always close to nature, could not be apart from the environment, and live united with nature in the environment where he lived. 


\section{DISCUSSION}

\section{The Landscape of Brayut Tourism Village}

Brayut is a tourism village which is located at Jalan Palagan-Brayut, Pendowoharjo, Sleman, Yogyakarta Special Region. Brayut which was inaugurated on 14 of August 1999, is a village that has a special characteristic in agriculture. The special characteristic in agriculture is caused by the strategic location of Brayut Village which is surrounded by rice fields. It is also makes Brayut known as the Inten Belt Region. The term Beluk Inten has the understanding that Brayut residents get a lot of sustenance through the agricultural business.

The Head of Farmer Group Brayut Village, Joko Susilarto revealed that belt means strap and inten means a diamond that is known valuable and has high selling value. Inten in this sense means rice fields that can provide opportunities for Brayut residents to seek sustenance. Understanding Belt Inten shows the understanding that Brayut residents gain prosperity because the region is tied or surrounded by rice fields. Joko also said that $80 \%$ to $85 \%$ of Brayut residents are farmers and the rest work as farmers, traders, civil servants, and private employees.

Brayut tourism village is one of the tourist villages that explores its local wisdom as a tourist destination. Brayut Tourism Village was established and inaugurated on $14 \mathrm{Au}-$ gust 1999. Brayut Village before becoming a tourist village was once a farm village. The change to become a tourist village was started by one of Brayut residents named Budi Utomo in 1990. Budi Utomo is a political science graduate from Gadjah Mada University Yogyakarta who works as a lecturer at AKINDO and a lecturer at Turi Indonesian Language Institute, Sleman. Budi Utomo's students at Turi Indonesian institution are mostly foreigners. Budi Utomo then often invites his students to interact and participate in community activities in his village Brayut. Budi Utomo in 1999 established the Ani-ani Foundation at his home in Brayut Village in order to develop an alternative tour for foreign or local tourists (Larasati, 2013: 2).
The village flanked by the river to the east and the moat in the west is quite easy to reach because of the district highway through the hamlet. The streets of the village look neat because it has been closed since the 1990s conblok. In some of the forks there are large rearview mirrors that make it easier for drivers or road users to know the vehicle from other directions. This is in addition to making the road users safe and comfortable, also gives the impression forward for the village Brayut (Larasati, 2013: 1).

The geographical condition of the village of Brayut, located in the north and close to the river flow from Merapi volcano, forms a fertile soil structure and paddy field. Rice fields in the village of Brayut is still suitable to be a place to grow rice, although not during the rainy season. The area of paddy field which is also close to the cattle farm of Brayut increasingly increase the fertility of the rice field. Brayut which in general is still surrounded by rice fields, along with the development of the era experienced a reduction in the area of rice fields due to the increase in the number of immigrant houses established over part of the land of Brayut Village. The area of rice fields in Brayut Village is now about 42 hectares and is owned by most Brayut residents (Rachmadani and Diaz Prasongko, 2014: 143).

Rice village in Brayut used as a medium for agricultural commodit i es production. Rice and maize are the village's most excellent commodities. In addition, the Brayut farm produces eggplants, chili, and long beans. Agricultural activities in one year experience two to three times the harvest. Rice fields in the rainy season mostly functioned for rice planting, while in the summer planted crops such as corn, eggplant, chili, and beans. In addition, there are agricultural products that are harvested in certain seasons such as tobacco (Susilarto, 2016).

Ecotourism is the Base of Agricultural Village Development Village of Brayut, Pendowoharjo, Sleman, Yogyakarta Special Region The village of tourism is "a form of integration between attractions, accommodation and supporting facilities presen ted in a community 
life structure that integrates with the prevailing rules and traditions". The difference between a tourist village and a city tour is seen in the structure of community life that can be used to classify it more clearly. The structure of village life is strongly influenced by the physical structure of the village and the pattern of village settlements. The physical structure of the village is strongly influenced by the physical environment with its various aspects, especially the geographical environment such as climate, rainfall, soil condition or type, soil height, humidity level, topography and others, as it will greatly affect the types of plants, farming systems and behavior patterns Farmers. So it is clear that in rural areas there are two main elements that affect the physical environment related to the location and culture of the population (Lang, 2005: 42-43).

Sleman Regency is a strategic area for Yogyakarta Special Region, because it is an agricultural area and as a source of water conservation in Yogyakarta, but it is also a fast growing area because this area is a center of education. The process of urbanization occurs very quickly due to the conversion of land from agriculture into settlements triggered by the campuses as a center of growth. The emergence of tourist villages in northern Sleman is expected to limit the conversion of the land considering the rural behavior that is likely to sustain the development of their tourism potential (Hwang, 2012: 21).

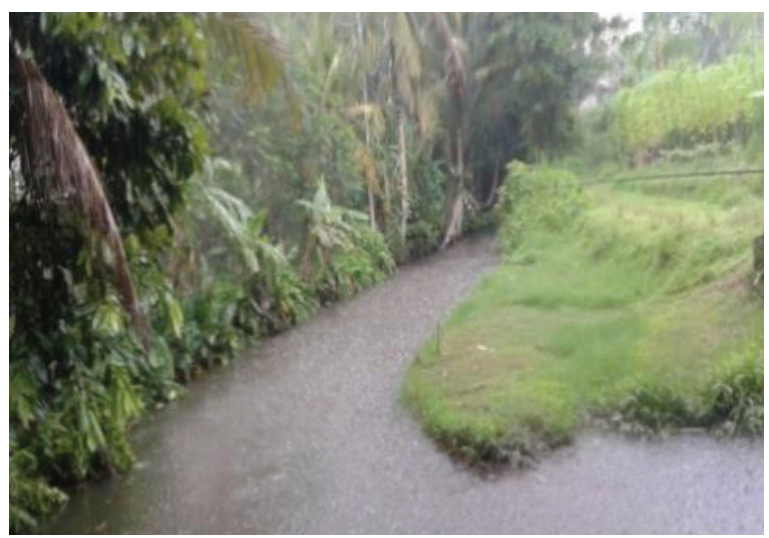

Figure 1. The Rivulet of Dasa, which is located in the north of Dam Kebo Kuning, has a fungtion to supply irrigation water for theree dams in Brayut Village: Kebo Kuning, Sejekol, and Slingi.

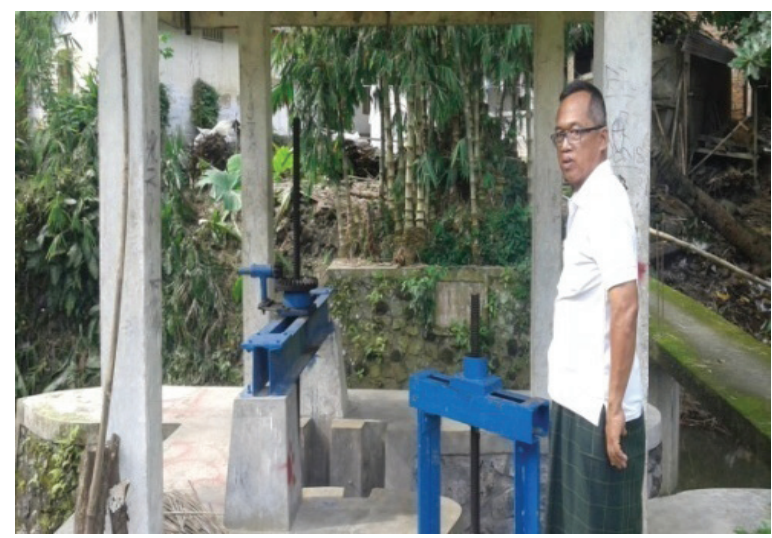

Figure 2. Joko Susilarto, the Head of Farmers Group Brayut Tourism Village, while observing Dam Sejengkol.

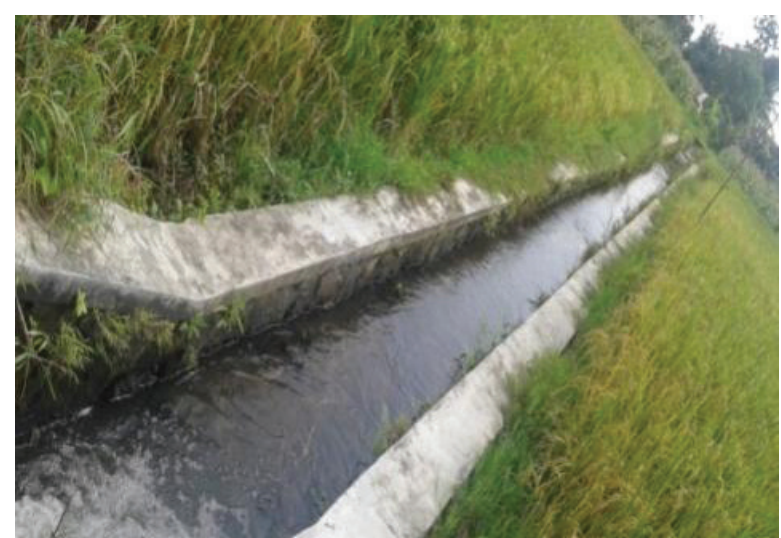

Figure 3. The Canal of Agriculture Irrigation Dam Kebo Kuning, has a fungtion to deliver water irrigation from Dam Kebo Kuning to the farm field.

Brayut is one of the village in the district of Pendowoharjo, Sleman, Special Region of Yogyakarta. Brayut Village offers a charming natural scenery with cool air that is still free from pollution. Tourists who come to Brayut Tourism Village will be invited to integrate with the local people's way of life in various activities that are strong in local wisdom, such as agriculture, batik, traditional dance, karawitan, culinary tour, traditional games, and cultural and environmental conservation activities Department of Culture and Tourism of Sleman Regency, 2010).

Brayut Tourism Village as one of the tourist village in Sleman Regency, located Pendowoharjo Village, Ngaglik Subdistrict, Sleman Regency, D.I Yogyakarta. Brayut 
Tourism Village is the first tourism village in Sleman District and used as an example for other tourism village candidates. Brayut hamlet consists of $4 \mathrm{RT}$ and $2 \mathrm{RW}$. The people of Brayut Hamlet mostly work as farmers, with the slogan of local-based agricultural wisdom. Brayut as a farm based village offers a charming natural scenery with cool air that is still free from pollution. Farm land in Brayut hamlet strived for the development of rice, corn, soybean, peanut, bean, and chili. This is supported by the availability of good water in the region. Land in the village of Brayut besides strived for agricultural activities is also used for the activities of tobacco plantations, coconut, and fruit crops such as salak, organic oranges, bananas, rambutan (Suharti, 2016: 12).

The tourists in the Brayut Village can learn to grow rice, feel the activities often done by farmers. After planting rice, tourists can enjoy the beautiful rice fields with a walk in the fields (tracking). Tourists who want to enjoy the package of rice fields are charged with a particular package. Money earned from tourists, some of which is destined for the owner of the rice field, which of course can increase the income of some people Brayut Hamlet. Other tourist activities, namely catching fish and bathing in the river. In addition to agricultural activities, Brayut Tourism Village also has livestock activities. Livestock that is attempted is cattle with the existence of Group of Livestock "Sumber Ayu". Livestock management is done jointly by cattle owners, from looking for grass, and cleaning the dirt (Suharti, 2016: 13-14).

Table 1.

Inventory Tourist Visitor of Brayut Village 2007-2013

\begin{tabular}{c|l|l|l}
\hline Year & Domestic & Foreign Tourist & Total Visitor \\
\hline 2007 & 632 & 13 & 645 \\
\hline 2008 & 832 & 16 & 848 \\
\hline 2009 & 1307 & 57 & 1364 \\
\hline 2010 & 1483 & 13 & 1496 \\
\hline 2011 & 2207 & 31 & 2238 \\
\hline 2012 & 3241 & 102 & 3343 \\
\hline 2013 & 3921 & 228 & 4149 \\
\hline
\end{tabular}

Source: The Report of "Kelompok Sadar Wisata Desa Wisata Brayut 2007-2013"
The village is etymologically defined as a group of out-of-town homes that are unity. Villages considered as opposed to the city are defined as beautiful, cool and green. The village is located in the capital of Sleman Regency is located not far from the city of Yogyakarta. Brayut Village, Pandowoharjo Village, Sleman Sub-district of Yogyakarta Special Region has many uniqueness. One of the uniqueness in Brayut Village that is environmental condition which is typical of belt inten. The inten belt is the name for the area surrounded by rice fields. Ancient agriculture is the main livelihood of Brayut people so that the rice fields are a diamond for the people of Brayut (Larasati, 2013: 1).

\section{The Manifestation of Environmental Awareness Attitude in the Agricultural Irrigation Tradition of Brayut Tourism Village}

The manifestation of the environmental awareness of Brayut society in the agricultural irrigation system of Brayut Village is a reflective explanation that sees the form of environmental awareness among Brayut society in establishing an agricultural irrigation system in Brayut Village. Description of the analysis of this section contains an explanation of the forms or manifestations of environmental awareness attitudes conducted by the people of Brayut Village in daily keeping the continuity of agricultural irrigation system in the village of Brayut. Brayut Village community in realizing the attitude of environmental awareness on agricultural irrigation system of Brayut Village also shows a deep understanding to maintain the sustainability, cleanliness, and environmental nature in the area of agricultural irrigation system of Brayut Village which is realized with the seriousness of maintaining agricultural irrigation system of Brayut Village (Rachmadani, 2017: 135-137).

Agricultural irrigation system in the village of Brayut is small because it utilizes the flow of tributaries that are not too big. The main river that became the source of Brayut Village irrigation flow from three major riv- 
ers namely Sempor, Dasa, and Denggung, located outside the village of Brayut. The distribution of irrigation water allocation was divided traditionally, according to the agreement of Brayut farmers who use irrigation water for agricultural purposes. Brayut society who mostly still work as farmers use irrigation water by following the regulation of the distribution of irrigation water allocation ration as Pendowoharjo. The regulation on the distribution of irrigation rents in Pendowoharjo has been established since the traditional dam in Pendowoharjo region functioned around 1980 (Susilarto, 2016).

Table 2.

List of Dam District in Pendowoharjo, Sleman, Yogyakarta Special Region

\begin{tabular}{l|l|l}
\hline River Name & \multicolumn{1}{|c|}{ River Dam } & \multicolumn{1}{|c}{ Dam Location } \\
\hline \begin{tabular}{l} 
River \\
\hline
\end{tabular} & Dam Makmur & $\begin{array}{l}\text { Mantaran } \\
\text { Trimulyo }\end{array}$ \\
\hline & Dam Megedangan & $\begin{array}{l}\text { Mantaran } \\
\text { Trimulyo }\end{array}$ \\
\hline & Dam Mantaran II & Karang Trimulyo \\
\hline $\begin{array}{l}\text { Dengar } \\
\text { Pandowoharjo }\end{array}$ \\
\hline & Dam Kacung & $\begin{array}{l}\text { Temon } \\
\text { Pandowoharjo }\end{array}$ \\
\hline & Dam Setalang & Krandon \\
\hline & Dam Majegan & Majegan \\
\hline & Dam Cangkring & Mancasan \\
\hline Dasa River & Dam Jetakan & Jetakan \\
\hline & Dam Sebo Kuning & Brayut \\
\hline & Dam Slingi & Brayut \\
\hline & Dam Kemaduh & Karayut \\
\hline & $\begin{array}{l}\text { Dam Kedung } \\
\text { Mas }\end{array}$ & Karangtanjung \\
\hline & Dam Seduren & Berkisan \\
\hline & Dam Sabrangan & Grojogan \\
\hline & Damang \\
\hline
\end{tabular}

Source: Inventory Data of Dam Area Pendowoharjo, Sleman, Yogyakarta Special Region.

Brayut Village has three traditional dams namely Kebo Kuning, Sejengkol, and Slingi. Kebo Kuning Dam is located northeast of the Brayut settlement, the Sejengkol dam is in the east of the Brayut settlement, while the
Slingi dam is located south of Brayut Village at the front door and into Brayut Village. Kebo Kuning Dam, Sejengkol, and Slingi as a unity agricultural irrigation system in Brayut Village has a primary function for agricultural activities in Brayut (Susilarto, 2016).

The three traditional dams that lie between the rice fields and the Brayut Village settlements also each have a special function in terms of agricultural purposes. Kebo Kuning Dam specifically serves as a source of irrigation flow for the needs of rice cultivation in a period of one year occurs three times the harvest. Bendungan Sejengkol specifically serves as a source of irrigation flows for the needs of rice crops and rice cultivation which in a period of one year occurs two harvests of rice and one crop of crops. Slingi Dam specifically serves as a source of irrigation flows for the needs of crops of crops of palawija which in one year period occurs three times the harvest. Kebo Kuning Dam, Sejengkol, and Slingi have approximately the same width of 8 to 10 m. Kebo Kuning Dam and the Sejengkol Dam have the capacity to provide irrigation water to run 40 to 50 hectares of paddy fields, while the Slingi dam has the capacity to provide irrigation water to run rice fields of less than 40 hectares or about 30 hectares (Susilarto, 2016).

Agricultural irrigation system in the village of Brayut is a small irrigation system or also known as traditional agricultural irrigation system. The traditional dam type of Brayut Village is based on its use, when it refers to the understanding and function of three types of dam according to Soedibyo including into the type of catch and water dam dam, i.e. dams that are constructed for higher water levels to satisfy the function of flowing in lower irrigation channels such as channels secondary irrigation and tertiary irrigation canals until the water finally reaches the rice fields. Kebo Kuning Dam located in the northeast of the Brayut settlement, which tends to be located in highland areas, has greater water discharge than Sejengkol and Slingi dam located in more areas (Susilarto, 2016). 
There are two types of dam that is to pass water and dam to hold water. Here's the division of the type of dam based on the way the water. First, the dam to pass water is a dam built to pass water. Second, the dam to hold water is a dam that absolutely can not pass water. Both types are usually built abutting and made of concrete, stone pairs or masonry. The objective is to control flood, drinking water supply, and industry as well as maintenance of environmental sustainability of the river (Soedibyo, 1993: 30-31).

The Brayut community generally supports the activities of village agriculture, as evidenced by the increasing efforts in the utilization of the three colonial relics dams located in residential areas and rice fields of Brayut. The dam, which is located in the north of Brayut Village named Kebo Kuning, then in the east named Sejengkol, and in the south called Slingi. The dam in the village of Brayut in general has never experienced drought because the river along the dam is filled with various trees with strong roots. The trees along the river banks of Brayut Village have strong roots that function to absorb the volume of water in large quantities. The variety of trees that grow in green spaces along the banks of the river Brayut Village namely Klueh, Cangking, Pereh, and Gayam, and Beringin. The various trees are good reservoirs of springs as they have strong roots with wide reaches deep underground (Susilarto, 2016).

Brayut Village has an area dominated by rice fields. Brayut farms are located in the vicinity of residential neighborhoods that specifically surround the village. Rice fields in the village of Brayut planted with rice crops and crops are not entirely planted on the same land. Rice crops are planted to the east of the Brayut settlement, while crops of palawija are planted in the west of the Brayut settlement. This is determined by the level of fertility as well as the flow of water flowing from the irrigated agricultural dam of Brayut Village. Rice fields to the east of the Brayut settlement relatively close to dams and rivers make the land more suitable for rice cul- tivation. Rice fields to the west of the Brayut settlement away from rivers and dams cause the land to be more suitable for cultivating crops (Sudarmadi, 2016).

Brayut society have always held the principles and teachings of the parents or founders of Brayut Village to implement environmental maintenance in the dam area Kebo Kuning, Sejengkol, and Slingi, then in the area of the tributary of Dasa, and in the area of rice fields of Brayut traditionally in order to realize the continuity agricultural irrigation system in Brayut Village to maintain its sustainability. Brayut society who live near agricultural irrigation areas and who live in remote locations from irrigated agriculture attempt to keep the environment clean and do not damage agricultural irrigation networks in the village of Brayut, although the Bray ut peo ple are not entirely engaged in agricultural irrigation. Brayut society often carry out activities in agricultural irrigation areas also maintain the cleanliness and neatness of the environment in the agricultural irrigation area of Brayut Village by continuing to maintain the natural conditions in three traditional dams along with the riverbed Dasa as well as the flow of the Dasa River (Susilarto, 2016).

Brayut society in the maintenance of agricultural irrigation systems in Brayut Village demonstrated an attitude of environmental awareness of the agricultural irrigation system of Brayut Village as part of the Brayut community of environment. Brayut society who are not entirely directly involved in agricultural irrigation activities in the village of Brayut, still take the attitude of environmental awareness that is seen in the daily life of the people of Brayut in maintaining the cleanliness and naturalness of the agricultural irrigation system area of Brayut Village. If the Brayut society do not have an environmental awareness attitude in carrying out the agricultural irrigation system of Brayut Village, then there is an opportunity at one time the area of agricultural irrigation system of Brayut Village is no longer sustained and its cleanliness (Rachmadani, 2017: 138-140). 
The manifestation of the Brayut community's environmental awareness in the sustainability of agricultural irrigation system of Brayut Village is also seen in the management of agricultural irrigation network and the dam of Sejengkol, Slingi, and Kebo Kuning which apply the traditional principle of harmony or harmony with nature. Brayut society in taking environmental awareness to the continuity of irrigation system of agriculture of Brayut Village to preserve the environment and environmental hygiene with the principle of natural harmony is to build a harmonious life in the middle of nature of Brayut Village as a form of maintenance of the living environment in the village of Brayut (Susilarto, 2016).

Brayut society in applying the principle of natural harmony as a form of environmental awareness are also seen in the maintenance of 'green spaces' in the area of agricultural irrigation system of Brayut Village such as planting some tree species that serves to store irrigation water source that is Klueh, Cangking, Pereh, and Gayam, and Banyan. Brayut society, especially those living in the agricultural irrigation system of Brayut Village, show an awareness of the attitude of building a healthy environment. Environmental awareness that is good for nature conservation such as water in agricultural irrigation system of Brayut Village can become the main support for the smoothness of agricultural activity and provide a healthy life for various types of plants around it, so the attitude of environmental awareness owned by the people of Brayut Village can have a positive impact for the environment as well as living creatures that live in the environment (Sudarmadi, 2016).

Environmental awareness is a state of awakening of the soul to something-in this context is the environment-and can be seen in the behavior and actions of each individual (Neolaka 1991: 37). The manifestation of the attitude of environmental awareness by Brayut Village farmers was also seen in the continuity of agricultural irrigation system of Brayut Village which in the context of the meaning of space and time cosmology shows the attitude of environmental awareness, that with the continuity of agricultural irrigation system in Brayut Village has become one of the necessary conditions for farmer community Brayut Village to manifest environmental awareness. Agricultural irrigation system in Brayut Village $t$ is not based on the attitude of environmental awareness by the surrounding community, there is a tendency to establish a natural agricultural irrigation system.

Rice village in Brayut used a medium for agricultural commodities production. Rice and maize are the village's most excellent commodities. In addition, the Brayut farm produces eggplants, chili, and long beans. Agricultural activities in one year experienced two to three harvests. Rice fields in the rainy season mostly functioned for rice planting, while in the summer planted crops such as corn, eggplant, chili, and beans. In addition, there are agricultural products that are harvested in certain seasons such as tobacco (Susilarto, 2016).

\section{Ecotourism as a Part of Human Nature Philosophy: A Harmony between Human and Nature in the Response an Environmental Problem}

In its early days, ecotourism was seen more as a type of travel and a specific market niche. Today, it is increasingly viewed as a travel concept or philosophy, based upon a set of principles that can, and should, be applied across the widest possible spectrum of the global tourism industry in an effort to make tourism truly sustainable and a positive benefit to the natural and cultural heritage of our planet. In that sense, ecotourism and nature travel should not be viewed as the same thing. A river-rafting trip through the jungle may be fun, may be interesting and may provide a great family vacation. But only if that trip directly promotes the protection of nature and tangibly contributes to the well-being of local people does it become ecotourism. 
The understanding that ecotourism has the potential to create support for conservation objectives in both the host community and in the visitor alike, through establishing and sustaining links between the tourism industry, local communities and protected areas will provide the basis for our journey and leads us into understanding the central issues of conservation and sustainability of natural and social environments. Places ecotourism within its historical context to connect it to the major philosophic and social currents that have contributed to its development. We focus here specifically on the human-nature relationship and the interaction between them as this will help us to understand the shift in the way nature is valued, both historically and philosophically, and how ecotourism fits into this change in values (Wearing \& John Neil, 2009: xiv).

Ecotourism is not just an activity, but also a philosophy which broad philosophy that encompasses many elements and often includes in some parts. The first, a belief in humanities harmony with nature. The second, attempts to alleviate (or eliminate) negative human impacts on the environment - atmospheric pollution, land degradation, etc. The third, the argument for all life having its own specific intrinsic value such as the arguments against economic growth and consumerism. It is a broad philosophical position which attempts to give validity to intrinsic value and which is holistic, strongly grounded in the biology and ecology of nature and rejects the view that the world is divided into mutually exclusive parts. Therefore it affirms the intrinsic interconnectedness of all things, both living and inert. It is a belief that the world is a shared web of life (Wearing and John Neil, 2009: 15-17).

Development of ecotourism based on ecotourism in Brayut, Pendowoharjo, Sleman, Yogyakarta Special Region comes from the sign of environmental crisis in Pendowoharjo, Sleman, Yogyakarta Special Region. The sign of environmental crisis which is appear to be a decrease in the amount of water discharge in the rice fields of Brayut tourist village as well as the reduced availability of irrigation water in the dam sector of Brayut Village. If the signs of environmental crisis are not responded to in a preventive manner by the local community, it could have the potential to cause serious environmental impacts as it is known that water is a major source of survival for humans, animals, and plants in the tourist village of Brayut (Susilarto, 2016 ).

The farmers of Brayut Village in particular in manifesting the attitude of environmental awareness are seen in the principle of natural harmony on the banks of the Dasa River which is the main function to save water reserves or conserve water resources for agricultural irrigation activities. Brayut society and Brayut Village farmers consciously maintain the naturalness and cleanliness of the environment in the Dasa River banks, because the Brayut people are aware that if the Dasa River banks are not conserved and well guarded, it certainly will disrupt the smooth irrigation system of agriculture in Brayut Village. Similarly with the maintenance of three traditional Brayut Village dams, the Brayut society and the Brayut society are generally concerned with the nature of the dam by continuing to pursue environmental hygiene in the dam area until water in the dam is maintained from waste or water pollution. The cleanliness of the water in the traditional dam in Brayut Village also allows for some species of fish to live in the dam water of the village of Brayut (Susilarto, 2016).

Brayut Village farmers who have the attitude of environmental awareness from many years ago until now is a form of living habits that have been built or applied since the founder of Brayut Village built agricultural irrigation system in the village of Brayut, that the continuity of agricultural irrigation system in Brayut Village as an essential part in the natural structure of Brayut Village. It has the potential have a positive impact on the environment if it is constantly being preserved.

The predecessors of the village of Brayut since ancient times and continued until the 
present generation chose to plant certain tree species in the riverbank area of Dasa River in Brayut Village to create a container for preserving irrigation water sources at the root of the tree. The old people of Brayut Village when planting Klueh, Cangking, Pereh, and Gayam trees, and Beringin have e s timated instinctively and intuitively that if along the banks of the tributary Dasa is not planted with trees that have high-capacity root resap in order to save water debit Irrigation, irrigation water reserves to irrigate rice fields in the village of Brayut will also run out of risk at a time limit that is not known for certain.

The predecessors of Brayut Village, followed by present-day Brayut societ $y$, are well aware of the importance of the function or role of the trees planted in the Dasa Riverbed area that automatically Bray ut community intuition leads to environm e ntal awareness such as seeking the conservation of irrigation water as a precaution in case of environmental problems beyond the measurable estimates (Susilarto, 2016).

The elder people as the predecessor of the village of Brayut who had a major role in the development of agricultural irrigation systems in the village of Brayut have also used the sensitivity of intuition to preserve the irrigation water as a form of environmental awareness for nature in the village of Brayut, thus showing that the position is not limited in taking The attitude of environmental awareness is not entirely determined by mathematical or physical measures to calculate the estimated reserves of water availability in traditional irrigation farming dams. The local community as well as the Brayut Village farmers can exert their intuitive abilities to establish an agricultural irrigation system in Brayut Village by following the sensitivity of natural instincts.

Brayut society in the developing of traditional agricultural irrigation system always need an efforts to maintaining a good environment around agricultural irrigation area and outside agriculture irrigation area because the attitude of environmental awareness on the continuity of traditional agricul- tural irrigation system is accompanied by the attitude of maintaining the cleanliness of the environment, use of water, and preserve green space such as planting several types of trees to store water debit so that in the dry season does not cause drought that disturb the environment. If the peasant community in Indonesia lives in a village that does not have an environmental condition similar to Brayut Village, the idea or idea to build a traditional farm-based irrigation system can be realized by looking at the suitability of the village condition to estimate further possibilities in carrying out traditional agricultural activities such as making the system Irrigation of artificial agriculture based on the traditional principles and rules that bind the whole element of agriculture itself so that the final object of making traditional agriculture irrigation system environmentally friendly can be achieved (Rachmadani, 2017: 136-138).

Environmental awareness is a state of awakening of the soul to something-in this context is the environment-and can be seen in the behavior and actions of each individual (Neolaka 1991: 37). Environmental awareness shows an attitude of consciousness that focuses on the reality of human life that is environmentally aware humans seen through behavior or action. Human means taking an environmentally conscious action to know the rules of the rules such as the value of beauty, cleanliness, and neatness to the environment and strive to preserve it. Thus formed a pattern of life based on the concept of harmony and environmental balance (Neolaka, 2008: 22).

If such exercises are ongoing, it will become commonplace, that is to become an environmentally conscious living habit. This environmentally conscious habit will evolve into a living culture that eventually becomes the attitude of human life. Indonesian people no longer need to be told to be aware of the environment because by itself the attitude and actions will live in accordance with environmental ethics, so that the environment is maintained and sustainable (Neolaka, 2008: 133). 
Every year more of the planet's natural resources are consumed or contaminated by its human population. Human survival needs drinkable water, breathable air and usable biological diversity. Natural ecosystems are the world's primary reservoirs for each of these. Ecosystems worldwide have been modified by human activities to various degrees. Areas of near-pristine wilderness and other littlemodified environments are continually reduced (Buckly, 2004: 5).

\section{CONCLUSION}

Brayut society in the developing a tourism village based on ecotourism is make a preventive action which is undertaken to realize the preservation of nature and environment. Brayut with a specific agricultural tourism village is committed to preserve the tradition of local wisdom of Brayut Village. Local wisdom in Brayut Village in the preserving nature and the environment became the basic of developing ecotourism in Brayut village. Brayut as a tourist village with excellence in the field of agriculture, making agricultural activities as a tourist choice for visitors or tourists Brayut Village. Tourists Brayut Village are invited to enjoy the natural scenery of Brayut Village while seeing or participating in agricultural activities. Ecotourism as the basis for the development of agriculture tourism village, also become a complementary unity between the basic concepts of nature tourism with the basic character of nature and the environment of the Brayut village.

Ecotourism as a concept of basic tourism village development, providing environmental impacts and social impacts in the community as a manifestation of the attitude of environmental awareness. The manifestation of the Brayut society environmental awareness can be seen in the preservation of the tradition of irrigation agricultural activities of Brayut Village in the form of maintenance and maintenance of agricultural irrigation systems such as maintaining the continuity of three traditional Brayut Village dams, keeping the main function of Dasa River
Children as the main source of irrigation water debit, agriculture irrigation, and maintaining the rice fields around the settlement of the village of Brayut which characterizes the "Sabuk Inten". Ecotourism as part of human nature philosophy is a mirror of a harmonious relationship between man and nature that is seen in the responsibility of man to his environment. Humans who basically live in nature, always depend on the environment to be located, so ecotourism as human nature philosophy pointing to a necessary condition that is owned by humans as well as the people of Brayut Village that could not be separated from the environment.

\section{ACKNOWLEDGEMENTS}

This paper is a part of the thesis research as a final task of Graduate School of Master Philosophy Faculty of Gadjah Mada University. The acknowledgment to Prof. Dr. Joko Siswanto as a thesis supervisor who has provide a guidance during the working on thesis. Academic S2 of Master Philosophy S2 Faculty of Philosophy, Gadjah Mada University which is made an important role in the process of permission arrangement. Brayut Tourism Village society, especially Joko Susilarto, as the Head of the Village Farmers Group of Brayut Village who helped to found a research resources. My sincere gratitude also goes to all the informants who did not hesitate and without suspicion provided data and shared the information. I would like to send a gratitude to the anonymous reviewer who gave a several comments, suggestions, also guidance, this article would not be possible to be published without a great support from the editor of the Jurnal Kawistara.

\section{BIBLIOGRAPHY}

Buckly, Ralf. 2004. Environmental Impact of Ecotourism, Oxford-UK: Cabi Publishing International.

Hwang, Doohyun. 2012. Community Behaviourand Sustainable Rural Tourism Development, Journal of Travel Research. 
Lang, Jon. 2005. "Urban Design : A Typology of Procedures and Products",UK: Elsevier Architectural Press Oxford.

Larasati, Theresiana Ani. 2013. Mengenal Kesenian dan Kerajinan Tradisional di Desa Wisata Brayut,

www.bpadjogja.info/public/article/515/ DESA_WISATA_BRAY T.pdf.

Neolaka, Amos. 2008. Kesadaran Lingkungan, Jakarta: PT Rineka Cipta.

Holden, A. 2005. Achieving a Sustainable Relationship Between Common Pool Resources and Tourism: The Role of Environmental Ethics, California-UK: Journal of Sustainable Tourism.

Rachmadani, Fadhila dan Diaz Prasongko. 2014. Dari Agraria ke Wisata Geliat Desa Wisata di Tengah Arus Globalisasi dan Pola Konsumsi Pariwisata, Yogyakarta: Jurnal Badan Penerbitan
Pers Mahasiswa Balairung Universitas Gadjah Mada Edisi 53/ Tahun XXIX/ 2014.

Rachmadani, Fadhila. 2017. Sistem Irigasi Pertanian Desa Brayut, Sleman, D.I. Yogyakarta dalam Perspektif Kosmologi Ruang dan Waktu, Yogyakarta: Sekolah Pascasarjana Program Studi S2 Ilmu Filsafat Fakultas Filsafat Universitas Gadjah Mada.

Soedibyo, 1993. Teknik Bendungan, Jakarta: PT Pradnya Paramita.

Suharti (ed.). 2016. Prosiding Seminar Nasional dengan Tema Penelitian dan PP Muntuk Mewujudkan Insan Unggul, Yogyakarta: UNY.

Wearing, Stephen and John Neil. 2009. Ecotourism: Impacts, Potentials, and Posibility?, UK: Elsevier Ltd. All right reserved. 